\title{
Hybrid PV-Wind Micro-Grid Development Using Quasi-Z-Source Inverter Modeling and Control - Experimental Investigation
}

\author{
Neeraj Priyadarshi' ${ }^{1}$, Sanjeevikumar Padmanaban 2,*, Dan M. Ionel ${ }^{3}$, Lucian Mihet-Popa ${ }^{4}$ and Farooque \\ Azam ${ }^{1}$ \\ 1 Department of Electrical and Electronics Engineering, Millia Institute of Technology, Purnea 854301 India; \\ neerajrjd@gmail.com (N.P.); farooque53786@gmail.com (F.A.) \\ 2 Department of Energy Technology, Aalborg University, 6700 Esbjerg, Denmark \\ 3 Power and Energy Institute Kentucky (PEIK), Department of Electrical and Computer Engineering, University of \\ Kentucky, 689 FPAT, Lexington, KY 40506-0046, Kentucky, United States; dan.ionel@uky.edu \\ 4 Faculty of Engineering, Østfold University College, Kobberslagerstredet 5, 1671 Kråkeroy-Fredrikstad,Norway; \\ lucian.mihet@hiof.no \\ * Correspondence: lucian.mihet@hiof.no (L.M.-P.); Tel.: +47-922-713-53
}

\begin{abstract}
This research work deals with the modeling and control of hybrid photovoltaic (PV) - Wind micro-grid using Quasi Z-Source inverter. This inverter provides better buck/boost characteristics, able to regulate the phase angle output, less harmonic content, no requirement of the filter and has high power performance characteristics over conventional inverter as major benefits. A SEPIC converter as dc-dc switched power apparatus is employed for maximum power point tracking (MPPT) functions which provides high voltage gain throughout the process. Moreover, a modified power ratio variable step (MPRVS) based perturb \& observe (P\&O) method has been proposed in the PV MPPT action which forces the operating point close to maximum power point (MPP). Practical responses justify the performance of hybrid PV-Wind micro-grid with Quasi Z-Source inverter structure.
\end{abstract}

Keywords: PV, MPRVS, Quasi Z-source inverter, MPP, SEPIC converter.

\section{Introduction}

Micro-grid comprises the combination of micro sources, energy stored devices and several loads which works as a controlled unit to deliver electric demand for miniature location. It supplies power generation with tremendous reliability as well as an affirmation to varying loads [1-3]. Fossil fuels and nuclear sources are treated as traditional energy sources which provide electricity and are not located nearer to the load point. As conventional energy sources are not environmentally friendly and due to long distance transmission, there is considerable power losses occur. Therefore, renewable energy sources have given more attention to generate alternative power by the researchers nowadays [4-8]. Distributed generating (DG) source viz. Solar, wind, fuel cell, hydro, tidal, etc. are considered as main renewable technology, which are highly flexible, expandable and has environmentally friendly behavior. The maximum power point tracking (MPPT) is the important constituent needed to achieve maximum power point (MPP) as an operating point which enables the utmost power extraction for renewable sources [910]. Several MPPT technique viz. Perturb \& Observe (P\&O), Incremental Conductance (INC), Fuzzy logic control (FLC), Artificial Neural Network (ANN), Particle swarm optimization (PSO), Ant Colony Optimization (ACO), Artificial Bee colony (ABC), Firefly Algorithm (FA) etc. is reviewed in the literature are unable to detect global peak point with partial shade situations [11-23]. In this research work, Modified Power Ratio Variable Step (MPRVS) based P\&O technique is proposed without PI controller 
utilization which reduces the power oscillation near to MPP compared to a conventional P\&O algorithm and provides prevention to battery charging from voltage fluctuation.

To avoid multi reversal generation occurrence in a micro-grid system, in this research work a Quasi ZSource inverter is employed [24-26]. DC-DC converter is considered a vital interface to achieve peak power generation from PV modules. In this work, high quality tracking behavior is achieved by employing single ended primary inductance converter (SEPIC) which provides high voltage gain with better buck/boost performance compared to other dc-dc switched power converters [27]. This research work organizes mainly IV sections. I Section discusses the micro-grid system with an extensive literature review of MPPT techniques, dc-dc converters with benefits of Z-source inverter. II, section presents the complete structure of hybrid PV-Wind micro-grid system. III, section explains the PV Generator modeling, wind turbine model, MPRVS based MPPT algorithm, design specifications of the SEPIC converter as well as modes of operations of Quasi Z-source inverter. IV, section presents the experimental results which validate the performance of the proposed hybrid PV-wind micro-grid system. The novelty of this research paper is MPRVS based advanced MPPT algorithm have neither been discoursed nor been utilized before for hybrid PV-wind micro-grid with Quasi Z-source inverter experimentally.

\section{Structure of Hybrid PV-Wind micro grid}

The proposed structure of a design a PV-Wind micro grid system is portrayed in Figure 1. The SEPIC based soft switching for MPPT action is controlled through an advanced MPRVS based P\& O MPPT. A quasi Z-source inverter with common grounding characteristics is employed to get high volt gain. Employed inverter operates in two modes of operation as shoot through and non-shoot through the states. In this manuscript, the two diode model based PV generator has the better power extraction capability in equated with the single diode model. The rotor of wind turbine is mechanically tied with a generator to produce electrical power.

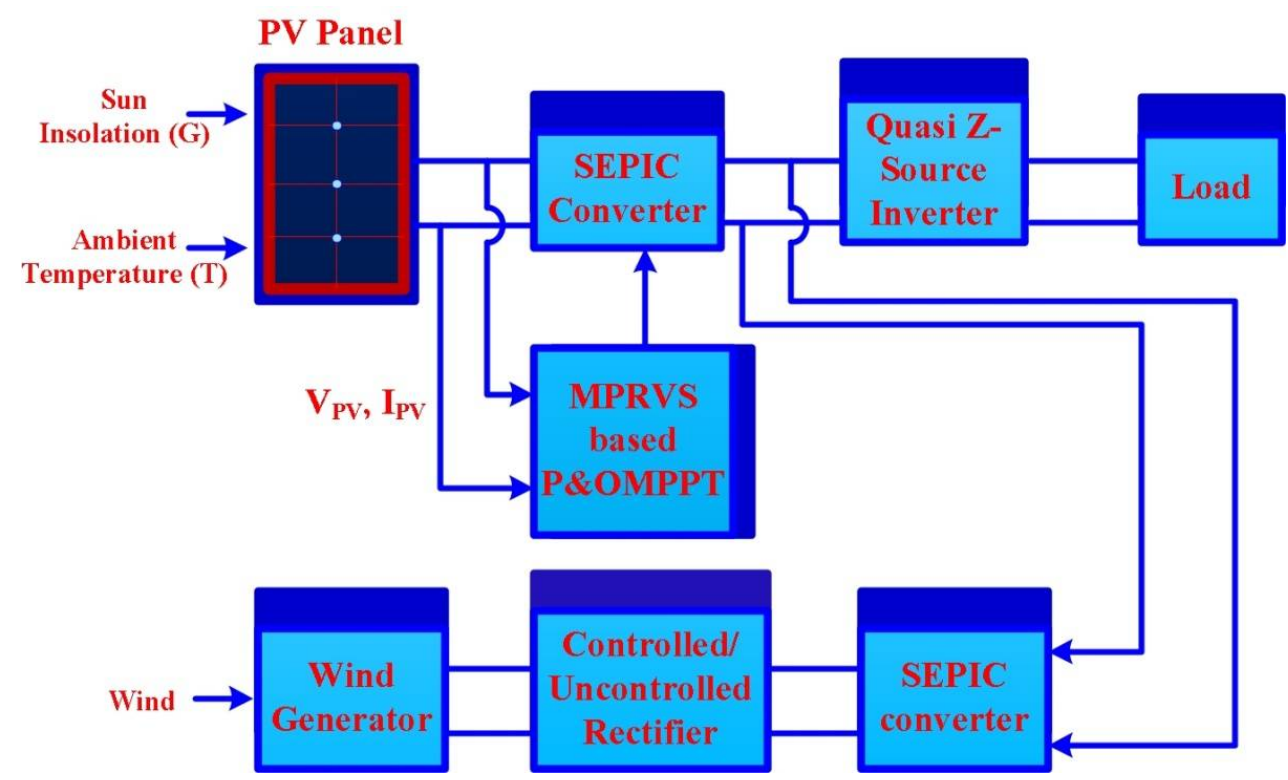

Figure 1. Structure of Hybrid PV-Wind micro grid

\subsection{PVG Mathematical Model}


Figure 2 illustrates the basic PV cell schematic diagram which is responsible to transform sun energy into electric power using photoelectric effect which comprises numerous cells. Here a two diode model is considered to deliver better accuracy compared to single diode model.

The PV cell output current is expressed mathematically as:

$$
I_{N}=I_{\text {Photon }}-I_{\text {Diode1 }}-I_{\text {Diode } 2}-\left(\frac{V_{N}+I_{N} R_{S E}}{R_{\text {Parallel }}}\right)
$$

Where,

$\mathrm{R}_{\mathrm{SE}}=$ Resistance in series

RParalle $=$ resistance in parallel

Also, Photon current is evaluated mathematically as:

$$
I_{\text {Photon }}=\left[I_{\text {Photon_STC }}+K_{S}\left(T_{C}-T_{S T C}\right)\right] * \frac{G}{G_{S T C}}
$$

Where,

Tsтc $=25^{\circ} \mathrm{C}=$ Temperature at STC (Standard Test Condition)

GsTc $=1000 \mathrm{~W} / \mathrm{m}^{2}=$ Solar irradiance at STC

$\mathrm{Ks}=$ Coefficient of short circuit current

$I_{\text {Photon_STC }}=$ Photo current at STC

$T_{C}=$ Ambient temperature

$\mathrm{G}=$ Sun insolation

Again,

Diode saturation current can be evaluated as:

$$
I_{\text {Diode1 } 1}=I_{\text {Diode } 2}=\frac{I_{\text {Short_STC }}+K_{S}\left(T_{C}-T_{S T C}\right)}{\exp \frac{\left[\left(V_{\text {open_STC }}+K_{V L}\left(T_{C}-T_{S T C}\right)\right]\right.}{V_{T h e r m a l}}-1}
$$

Where,

IShort_STC= Short circuit current at STC

$\mathrm{V}_{\text {open_STC }}=$ Open circuit current at STC

$\mathrm{V}_{\text {Thermal }}=$ Diode thermal voltage

$\mathrm{KvL}_{\mathrm{v}}=$ Voltage temperature coefficient 


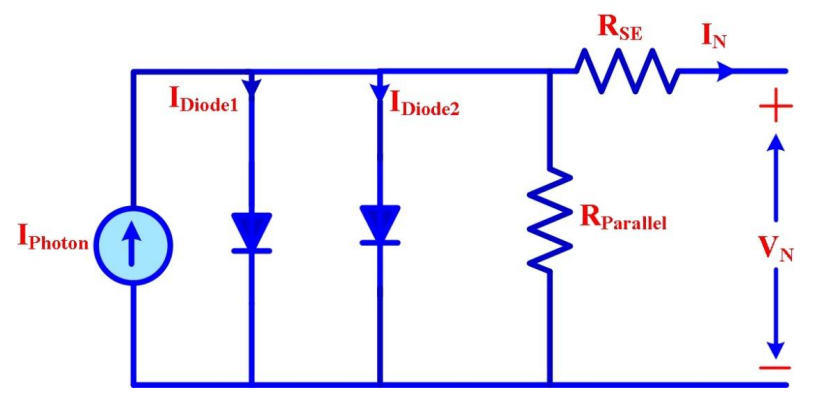

Figure 2. Basic PV cell schematic diagram

\subsection{Wind turbine modeling}

The working of wind turbine depends on wind velocity in which rotors are mechanically linked with generator. CPR (Performance coefficient) Vs tip speed $\left(\lambda_{\text {T.S }}\right)$ curve is plotted for different $\beta$ P.B (Pitch blade angle) which is depicted in Figure 3. Generated mechanical energy output from wind turbines can be written using equation (4) which is depending on wind velocity ( $\mathrm{VWind}_{\text {}}$ ), $\mathrm{R}_{\mathrm{T}}$ (Turbine radius) and $\mathrm{CPR}_{\mathrm{PR}}$ (Performance coefficient) as:

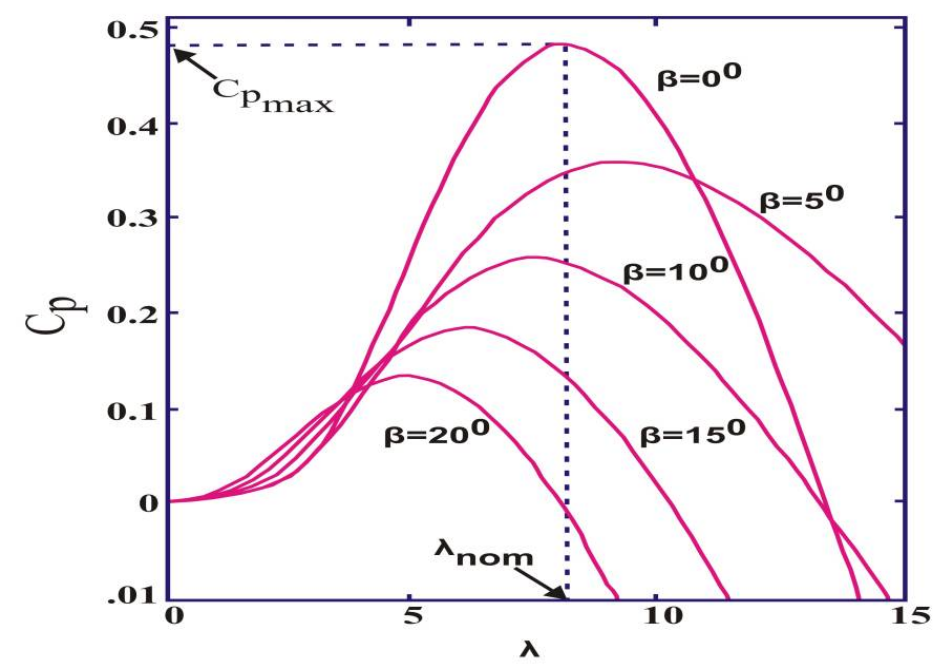

Figure 3. CPR (Performance coefficient) Vs tip speed $\left(\lambda_{\mathrm{T} . \mathrm{S}}\right)$ curve is plotted for different $\beta$ р.в (Pitch blade angle)

$$
P_{\text {Mechanical }}=\frac{1}{2} C_{P R} \pi R_{T}^{2} \rho_{\text {a.d }} V_{\text {Wind }}^{3}
$$

Where,

$\rho_{a . d}=$ Air density

Also, ratio of tip speed $\left(\lambda_{\mathrm{T} . \mathrm{S}}\right)$ can be described mathematically which is correlated with an angular velocity of blade ( $\left.\omega_{\mathrm{A} . \mathrm{V}}\right)$, $\mathrm{VW}_{\text {Wind }}$ and $\mathrm{R}_{\mathrm{T}}$ as:

$$
\lambda_{T . S}=\frac{\omega_{A . V^{*} R_{T}}}{V_{W \text { ind }}}
$$

And coefficient of performance is expressed with $\lambda_{\text {T.S }}$ and $\beta$ Р.в (Pitch blade angle) as: 


$$
C_{P R}\left(\lambda_{T . S}, \beta_{P . B}\right)=0.72\left[\frac{150}{\lambda_{j}}-2 * 10^{-3} \beta_{P . B}-131 * 10^{-1}\right] e^{\frac{-185 * 10^{-1}}{\lambda_{j}}}
$$

Where,

$$
\begin{aligned}
\frac{1}{\lambda_{j}} & =\frac{1}{\left(\lambda_{T . S}+8 * 10^{-2} \beta_{P . B}\right)}-\frac{35 * 10^{-3}}{1+\beta_{P . B}^{3}} \\
\lambda_{T . S} & =\frac{\omega_{G} * R_{T}}{V_{\text {Wind }} * \eta_{\text {gear }}} \\
\eta_{\text {gear }} & =\frac{\omega_{G M} * R_{T}}{\lambda_{T . S} V_{\text {Wind }}}
\end{aligned}
$$

Where,

$\omega_{G}=$ Speed of the generator

$\omega_{G M}=$ Peak allowed generator speed

$\eta_{\text {gear }}=$ Gear ratio

\subsection{SEPIC Converter Model}

Single ended primary inductor converter (SEPIC) is considered as an impedance adapter between PV module and Z-source inverter as it provides high gain throughout the operation, better voltage performance and high voltage rating for lower/higher power requirements. When boost converter combines with additional inductor and capacitor, a SEPIC converter is developed. In contrast with buck boost converter, the polarity of SEPIC is kept positively depicted using Figure 4 . Table 1 portrays the employed SEPIC converter parameters during implementation.

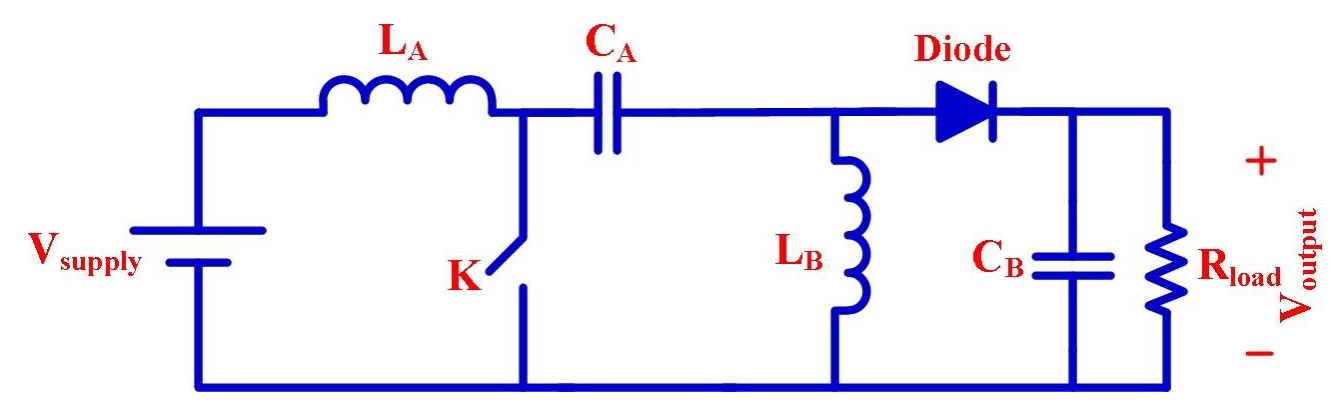

Figure 4. SEPIC converter

$$
\begin{aligned}
V_{\text {output }} & =V_{\text {supply }} * \frac{D_{\text {duty }}}{1-D_{\text {duty }}} \\
L_{A} & =\frac{V_{\text {supply }} * D_{\text {duty }}}{\Delta I_{L_{A}} * f_{\text {switching }}} \\
L_{B} & =\frac{V_{\text {supply }} * D_{\text {duty }}}{\Delta I_{L_{B}} * f_{\text {switching }}} \\
C_{A}= & \frac{V_{\text {output }} * D_{\text {duty }}}{R_{\text {Load }} * \Delta V_{o} * f_{\text {switching }}}
\end{aligned}
$$




$$
C_{B}=\frac{V_{\text {output }} * D_{\text {duty }}}{R_{\text {Load }} * \Delta V_{o} * f_{\text {switching }}}
$$

Where,

$\Delta I_{L_{A}}=\Delta I_{L_{B}}=$ Current ripple

$\Delta V_{o}=$ Ripple voltage

$f_{\text {switching }}=$ Switched frequency

Table 1. SEPIC converter parameter

\begin{tabular}{|c|l|l|}
\hline S.N & Parameters & Value \\
\hline 1. & Inductors $\left(L_{A}=L_{B}\right)$ & $0.42 \mathrm{mH}$ \\
\hline 2. & Capacitors $\left(C_{A}=C_{B}\right)$ & $3.5^{*} 10^{-3} \mu \mathrm{F}$ \\
\hline 3. & Current ripple $\left(\Delta I_{L_{A}}=\Delta I_{L_{B}}\right)$ & $0.5 \mathrm{~A}$ \\
\hline 4. & Voltage ripple $\left(\Delta V_{o}\right)$ & $1^{*} 10^{-3} \mathrm{~V}$ \\
\hline 5. & Switching frequency $\left(f_{\text {switching }}\right)$ & $20 \mathrm{~Hz}$ \\
\hline
\end{tabular}

\subsection{Modified Power Ratio Variable step based P\&O MPPT}

Figure 5 demonstrates the working model of MPRVS based P\&O technique for optimal PV power extraction from solar modules. The generation of gating pulses to the SEPIC converter is possible without the action of PI controller, which makes the reduction of power oscillation nearer to MPP and forces operating point close to MPP. It also prevents the battery charging system from over voltage.

The instantaneous power obtained through PVG $\left[P_{P V}(N)\right]$ at SEPIC output terminal is calculated as:

$$
P_{P V}(N)=V_{0}(N) * I_{P V}(N)
$$

Where,

$V_{0}(N) \& I_{P V}(N) \equiv$ Sensed voltage and current

Also, previous instantaneous power is mathematically described as:

$$
P_{P V}(N-1)=V_{P V}(N-1) * I_{P V}(N-1)
$$

And 


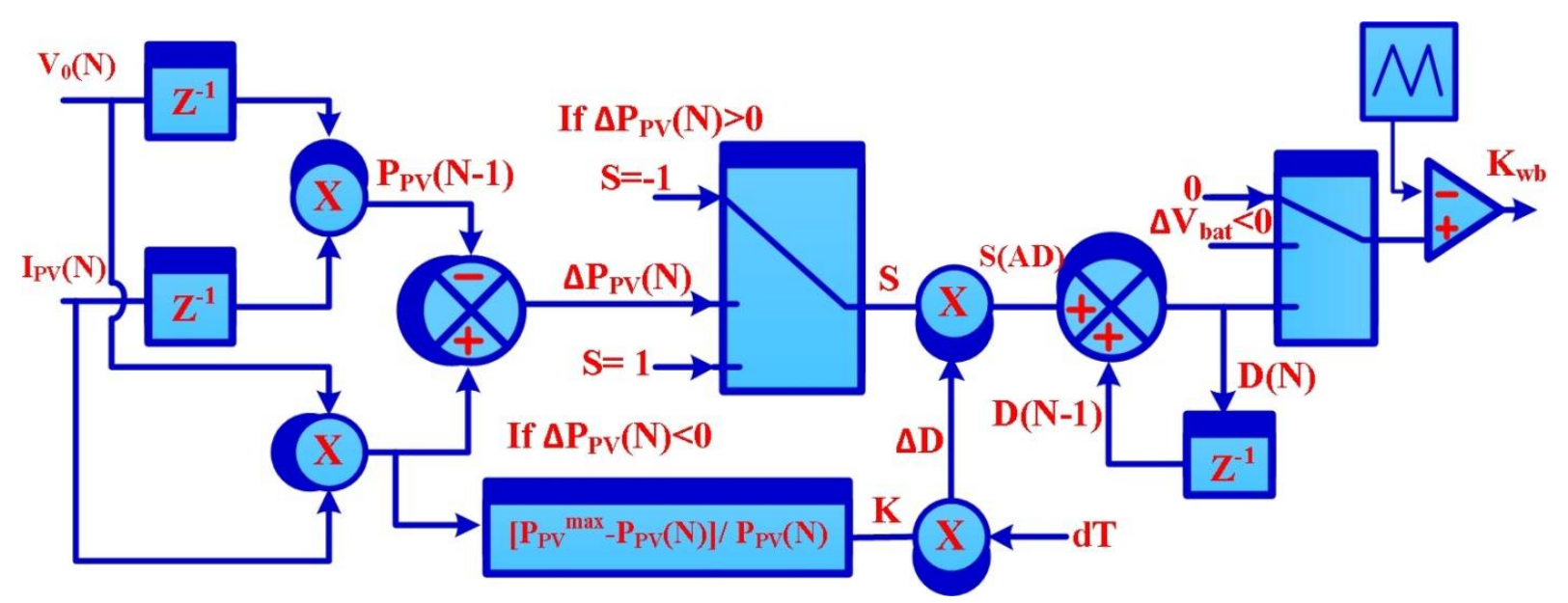

Figure 5. Working model of MPRVS based P\&O technique

If $\quad \Delta P_{P V}(N)=P_{P V}(N)-P_{P V}(N-1)>0, S=-1$

$\& P_{P V}(N)-P_{P V}(N-1)<0, \mathrm{~S}=+1$

Again,

$$
D(N)=D(N-1)+S * \Delta D
$$

$\Delta D \equiv$ Step perturbation of duty ratio $=K * d T$

$\mathrm{dT}=$ Fixed step size

$\mathrm{K}=$ Variable power ratio

$$
K=\frac{P_{P V}^{\max }-P_{P V}(N)}{P_{P V}(N)}
$$

\subsection{Quasi Z-Source Inverter mathematical modeling}

Figure 6 presents the equivalent power circuit of Quasi Z-source inverter which comprises $\mathrm{LA}_{\mathrm{A}}, \mathrm{LB}_{\mathrm{B}} \mathrm{C}_{\mathrm{A}}, \mathrm{C}_{\mathrm{B}}$ components with impedance circuit. The considered Z-Source Quasi inverter has no filter requirement, better buck/boost characteristics, able to regulate the phase angle output, less size, continuous conducting mode working, less harmonic content, high efficiency and with better power performance over a conventional inverter as major advantages. The Quasi Z-source inverter operates in two modes of operation. In non-shoot mode, the equivalent circuit has 6 active states with 2 zero states. Let Ts is the total switched inverter with $\mathrm{T}_{\mathrm{A}}$ and $\mathrm{T}_{\mathrm{B}}$ as shoot through state and non-shoot through state, respectively.

The duty ratio $D_{\text {duty }}$ of SEPIC converter is mathematically written as:

$$
D_{\text {duty }}=\frac{T_{A}}{T_{S}}
$$




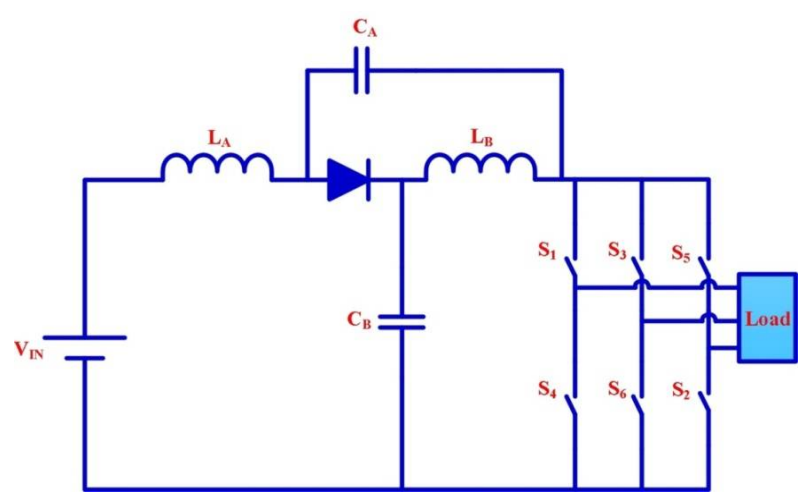

Figure 6. Equivalent power circuit of Quasi Z-source inverter

Mode I: The equivalent model of Quasi Z-source inverter is depicted in Figure 7 and mathematical equations governing non-shoot through state is expressed as:

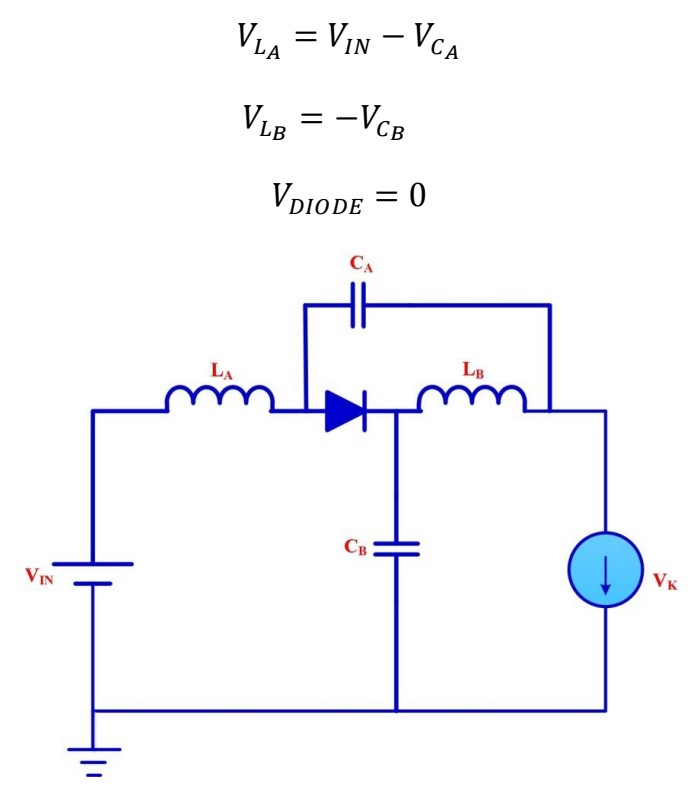

Figure 7. The equivalent model of Quasi Z-source inverter governing non-shoot through state

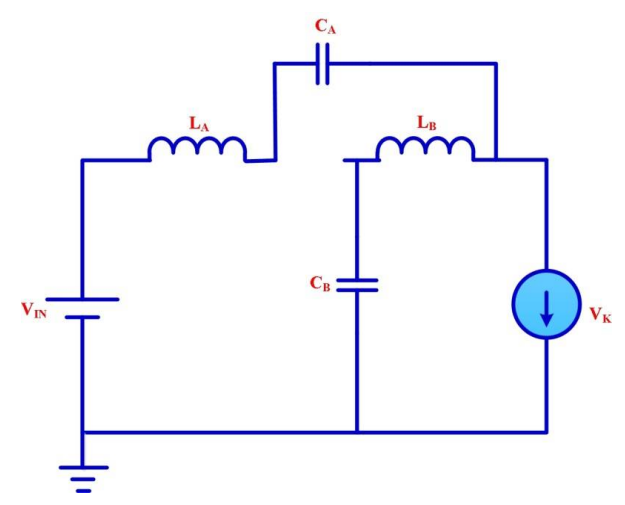

Figure 8. Equivalent model of Quasi Z-source inverter in shoot through state 
Mode II: Figure 8 illustrates the equivalent model of Quasi Z-source inverter in shoot through state mode with mathematical expression as:

$$
\begin{gathered}
V_{L_{A}}=V_{I N}+V_{C_{A}} \\
V_{L_{B}}=V_{C_{B}} \\
V_{D I O D E}=V_{C_{A}}+V_{C_{B}}
\end{gathered}
$$

Under steady condition, the average inductor voltage becomes zero.

$$
\begin{aligned}
& V_{L_{A}}=\left[\frac{\left(V_{I N}+V_{C_{B}}\right) T_{A}+\left(V_{I N}-V_{C_{A}}\right) T_{B}}{T_{S}}\right]=0 \\
& V_{L_{B}}=\left[\frac{V_{C_{A} T_{A}+\left(-V_{C_{B}}\right) T_{B}}}{T_{S}}\right]=0
\end{aligned}
$$

On solving above equations, capacitor voltage $\left(V_{C_{A}} \& V_{C_{B}}\right)$ are calculated mathematically as:

$$
\begin{aligned}
& V_{C_{A}}=\left(\frac{T_{B}}{T_{B}-T_{A}}\right) * V_{I N} \\
& V_{C_{B}}=\left(\frac{T_{A}}{T_{B}-T_{A}}\right) * V_{I N}
\end{aligned}
$$

Maximum voltage across DC-link $=V_{C_{A}}+V_{C_{B}}$

Putting equation 26 and 27 in 28 we get

$$
\text { Maximum DC-link voltage }=\left|\frac{1}{1-2 \frac{T_{A}}{T_{S}}}\right| V_{I N}=K * V_{I N}
$$

Where,

\section{$\mathrm{K}=$ Boost coefficient}

\section{Experimental Results}

The considered hybrid PV-Wind micro grid is tested using MPRVS based P\&O MPPT with employed Zsource inverter. Figure 9 depicts the developed practical structure of the proposed hybrid micro grid. The SEPIC converter is controlled through MPRVS based P\& O based MPPT in which LV-25P and LA-25P sensors are employed for $\mathrm{VPV}_{\mathrm{PV}}$ and IPV measurement. The power factor coefficient and THD are evaluated using a power quality analyzer (FLUKE 43B) and IGBT (IRG4PH50U), diode (Freewheel RHRG30120), driver circuit (HCPL 3120) etc. have been used as major circuit constituents. PMSG based wind emulator system is employed with interfaced dc-motor. The switched mode power converter makes the wind turbine as varying wind system which produces required torque by controlling wind turbine characteristics. The accuracy of proposed MPRVS based P\& O based MPPT has been tested with changing wind operating condition depicted in Figure 10 (a). The employed controller works in MPP area and provides optimal tracking of wind power under abruptions of wind velocity shown in Figure 10 (b). The corresponding duty ratio of SEPIC converter is generated and illustrated using Figure 10 (c). Furthermore, the capability of proposed MPPT tracker is examined with step varying solar insolation. 


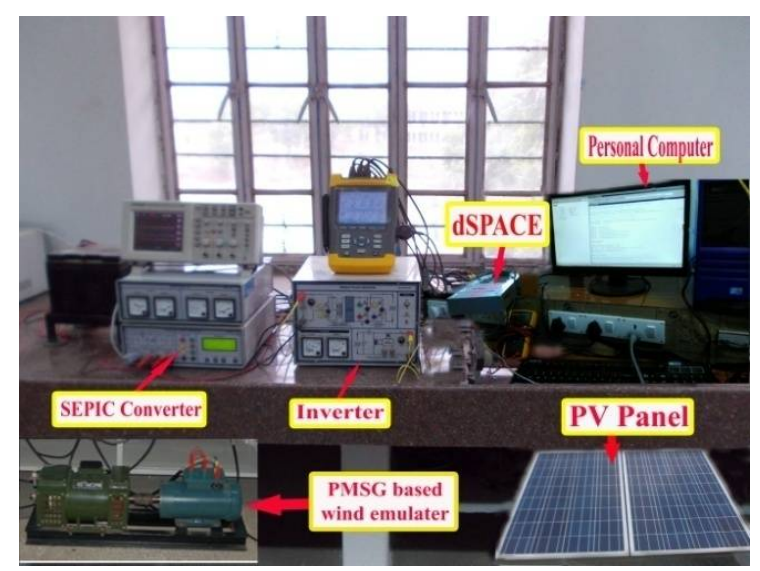

Figure 9. Developed practical structure of proposed hybrid micro grid

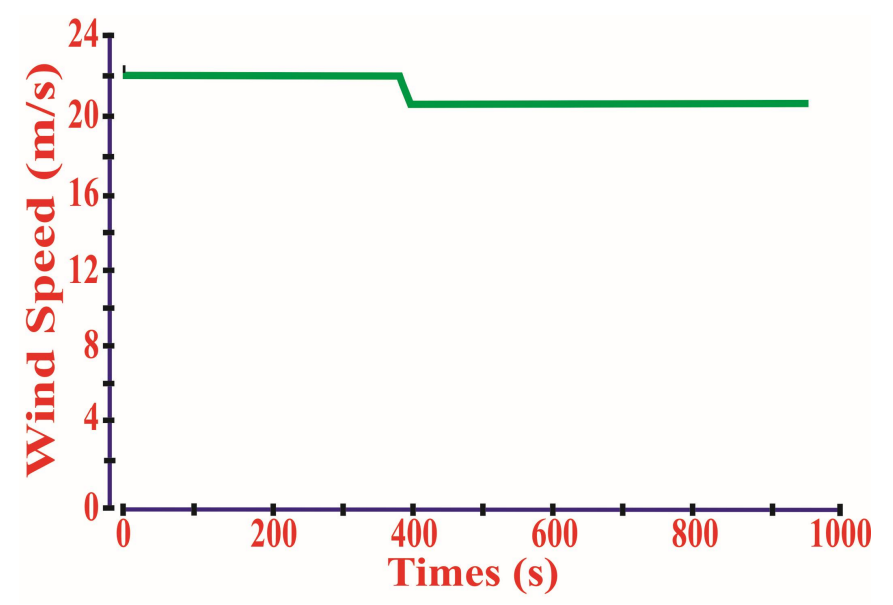

(a)

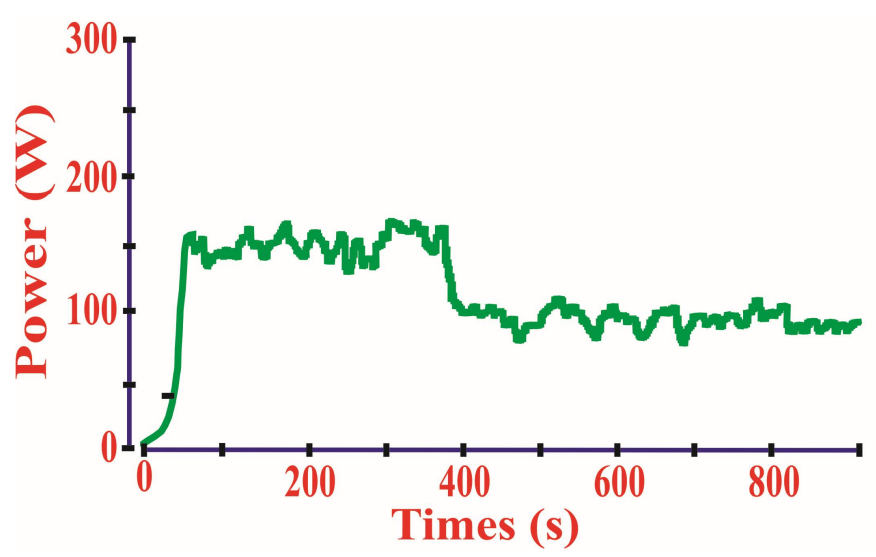

(b) 


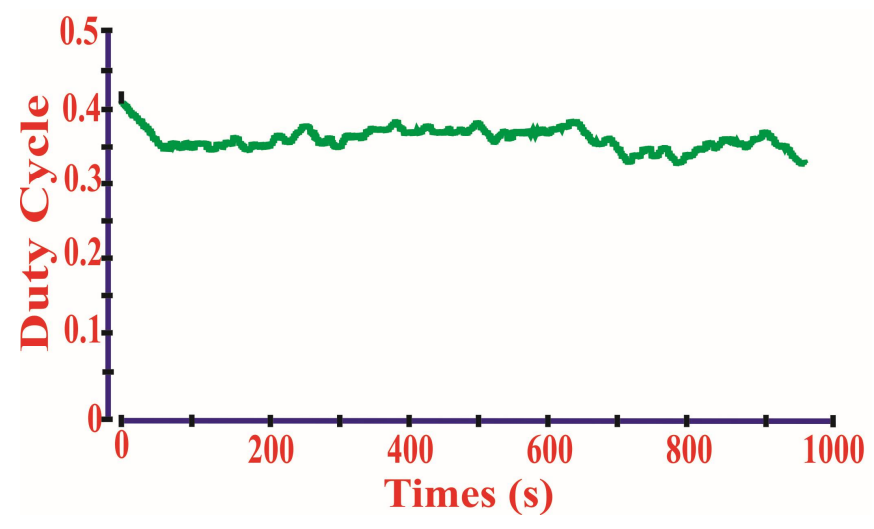

(c)

Figure 10. Obtained practical responses (a) wind speed variation (b) wind power (c) Duty cycle of Cuk converter

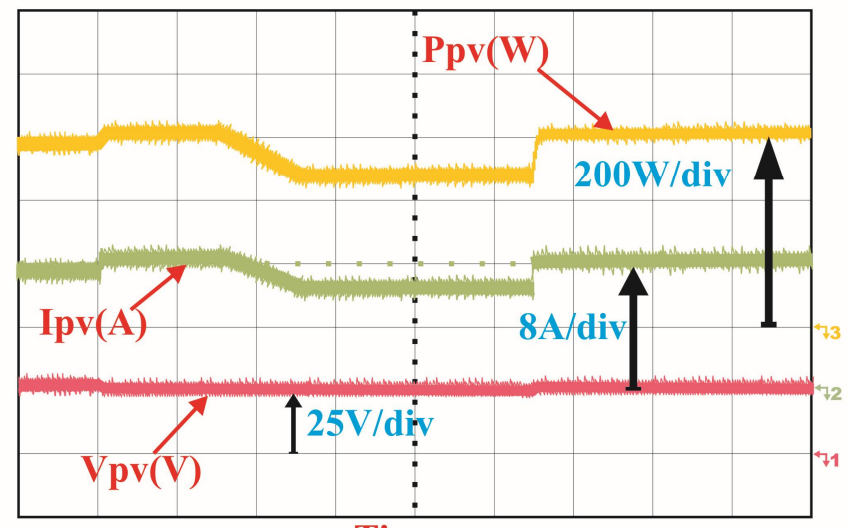

Time $\rightarrow$

Figure 11. PV responses under fluctuating atmosphere

Figure 11 demonstrates the PV array has obtained parameters under abrupt operating situations and has high accuracy and effective PV tracking in MPP region. The obtained experimental responses in Figure 12 (a) illustrate the performance of the proposed hybrid micro grid under varying wind velocity and constant solar insolation. Also, Figure 12 (b) demonstrates the behavior responses of the hybrid micro grid under varying solar irradiance and constant wind velocity with MPRVS based P \& O MPPT employed. The performance of the hybrid micro grid is tested in the absence of wind velocity and during this operation; the load is connected/disconnected to the utility grid, which is interpreted using Figure 13 (a) load cutting condition Figure 13 (b) Load removing conditions. The performance of the wind generator is evaluated under disconnecting/reconnecting operating conditions to the micro grid, which are depicted by Figures 14 and 15 and reveal the accurate performance of the proposed hybrid micro grid in varying operating situations (disconnecting operating conditions to the micro grid and reconnecting operating conditions to the micro grid), respectively. 


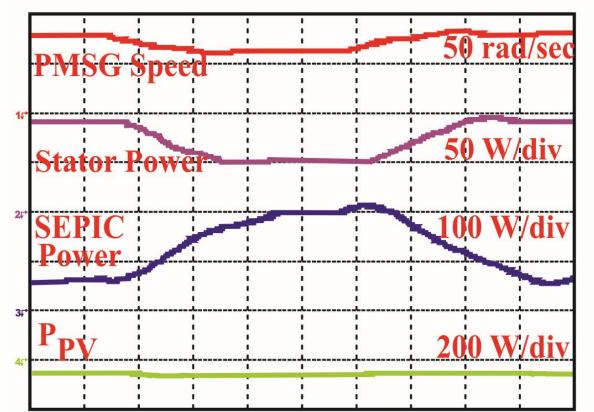

Time(sec) $\longrightarrow$

(a)

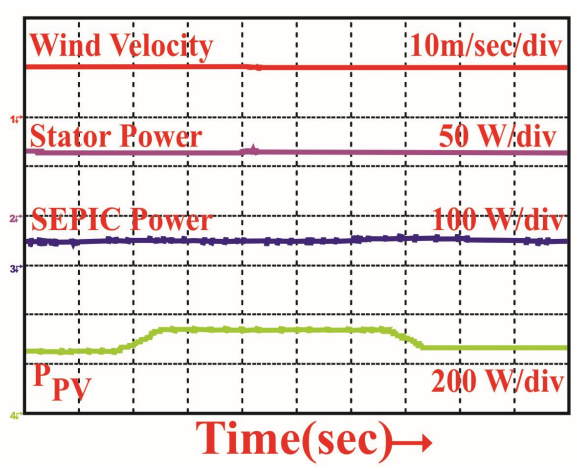

(b)

Figure 12. (a) Capability of proposed hybrid micro grid under varying wind velocity and constant solar insolation. (b) Behavior responses of the hybrid micro grid under varying solar irradiance and constant wind velocity

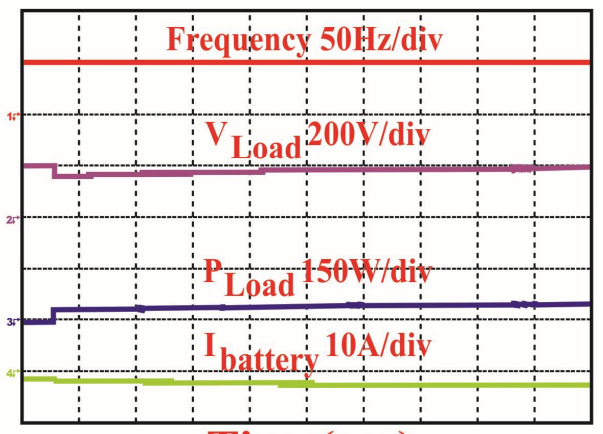

Time(sec) $\longrightarrow$

(a)

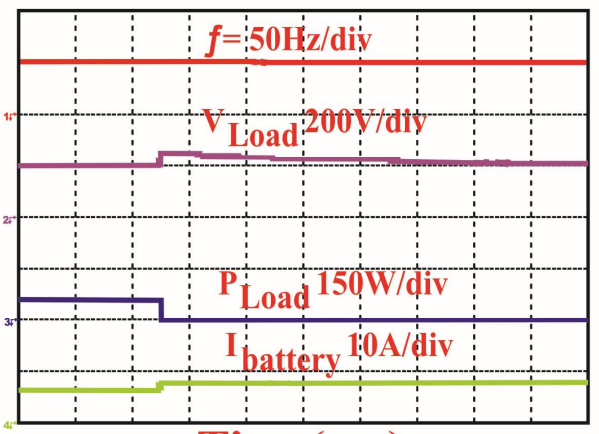

Time(sec) $\longrightarrow$

(b)

Figure 13. The performance of the hybrid micro grid (a) load cutting condition (b) Load removing condition.

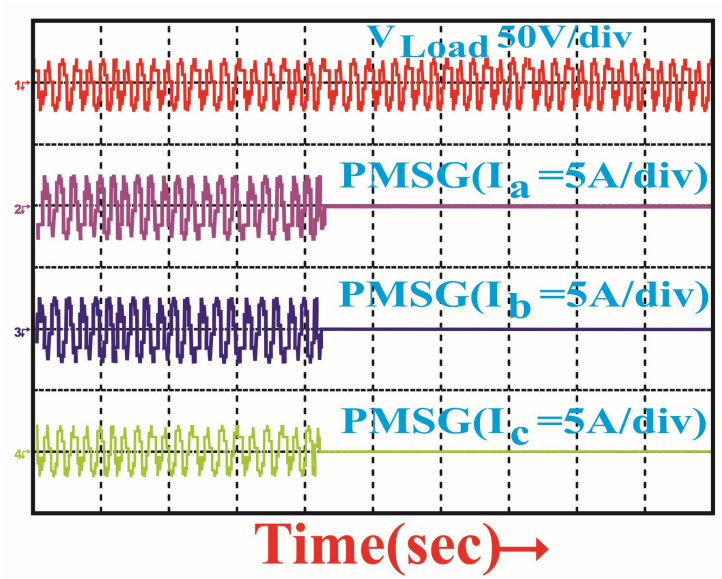

Figure 14. The performance of the wind generator is evaluated under disconnecting operating conditions to the micro grid 


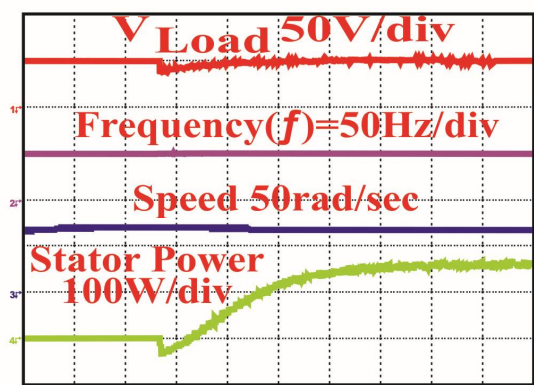

Time(sec) $\longrightarrow$

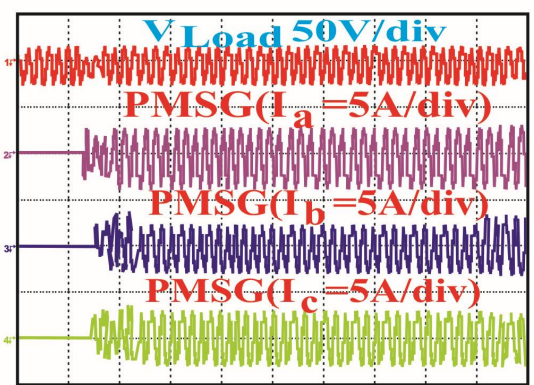

Time(sec) $\longrightarrow$

Figure 15. The performance of the wind generator is evaluated under reconnecting operating conditions to the micro grid

\section{Conclusion}

The proposed hybrid PV-Wind micro-grid system using Quasi Z-source inverter is realized practically with dSPACE (DS 1104) kit. The MPRVS based P\&O MPPT performance with SEPIC converter has been validated effectively, which delivers MPP achievement with low power oscillation for a PV system. The performance of Quasi Z-source inverter has been evaluated experimentally as has better buck/boost characteristics with fast dc-link voltage regulation under different operating conditions. Practical results reveal that optimal power has been tracked through PV-Wind renewable sources. Also, the two diode model based PV Generator provides high power extraction compared to single diode model.

\section{References}

[1] Tiwari, S.K.;Singh, B.; Goel P.K. Design and Control of Micro-Grid fed by Renewable Energy Generating Sources. IEEE Trans. Ind. Appl.Jan. 2018, 54, 2041-2050, doi: 10.1109/TIA.2018.2793213.

[2] Mi, Y.; Zhang, H.; Tian, Y.; Yang, Y.; Li, J.; Li J.; Wang, L. Control and Operation of Hybrid Solar/Wind Isolated DC Micro grid. In Proceedings of IEEE Conf. and Expo Transportation Electrification Asia-Pacific (ITEC Asia-Pacific). 2014, pp. 1-5.

[3] Shastry, A.; Suresh, K.V.; Vinayaka, K.U. Hybrid Wind-Solar Systems using Cuk-Sepic Fused Converter with Quasi-Z-Source Inverter. In Proceedings of IEEE Power, Communication and Information Technology Conference (PCITC). 2015, pp. 856 - 861.

[4] Kassem, A.M.; Zaid, S.A. Optimal Control of a Hybrid Renewable Wind/ Fuel Cell Energy in Micro Grid Application. In Proceeding of Nineteenth International Middle East Power Systems Conference (MEPCON), Menoufia University, Egypt, 19-21 Dec.2017, pp. 84-90.

[5] Tiwari, S.K.;Singh, B.; Goel P.K. Design and Control of Micro-Grid fed by Renewable Energy Generating Sources.In Proceedings of IEEE 6th International Conference on Power Systems (ICPS) 2016, pp. 1-6.

[6] Ahmed, J.; Salam,Z. An Enhanced Adaptive P\&O MPPT for Fast and Efficient Tracking Under Varying Environmental Conditions. IEEE Trans. Sustain. Energy. 2018, 1-10, doi: 10.1109/TSTE.2018.2791968.

[7] Vavilapalli, V.; Umashankar, S.; Sanjeevikumar, P.; Ramachandramurthy, V.K. “Design and RealTime Simulation of an AC Voltage Regulator based Battery Charger for Large-Scale PV-Grid Energy Storage Systems", IEEE Access Journal, IEEE Publications, 11 Oct. 2017.

[8] Hussain, S.; Alammari, R.; Jafarullah, M., Iqbal, A., Sanjeevikumar, P. "Optimization Of Hybrid Renewable Energy System Using Iterative Filter Selection Approach", IET Renewable Power 
Generation (RPG) Journal, IET Publication (United Kingdom), vol. 11, no. 11, pp. 1440-1445, Sept. 2017.

[9] Priyadarshi, N.; Kumar, V.; Yadav, K.; Vardia, M. An Experimental Study on Zeta buck-boost converter for Application in PV system. In Handbook of Distributed Generation; Springer: Cham, Switzerland, 2017; pp. 393-406, doi:10.1007/978-3-319-51343-0_13.

[10] Priyadarshi, N.; Anand, A.; Sharma, A.K.; Azam, F.; Singh, V.K.; Sinha, R.K. An Experimental Implementation and Testing of GA based Maximum Power Point Tracking for PV System under Varying Ambient Conditions Using dSPACE DS 1104 Controller. Int. J. Renew. Energy Res.2017, 7, 255-265.

[11] Kumar, N.; Hussain, I.; Singh, B.; Panigrahi, B.K. Framework of Maximum Power Extraction from Solar PV Panel using Self Predictive Perturb and Observe Algorithm. IEEE Trans. Sustain. Energy2017, 9, 895-903.

[12] Elgendy, M.A.; Zahawi, B.; Atkinson, D.J. Assessment of the Incremental Conductance Maximum Power Point Tracking Algorithm. IEEE Trans. Sustain. Energy2013, 4, 108-117.

[13] Zamora, A.C.; Vazquez, G.; Sosa, J.M.; Rodriguez, P.R.M.; Juarez, M.A. Efficiency Based Comparative Analysis of Selected Classical MPPT Methods. In Proceedings of the IEEE International Autumn Meeting on Power, Electronics and Computing,Ixtapa, Mexico, 8-10 November 2017; pp. 16.

[14] Abu-Rub, H.; Iqbal, A.; Ahmed, SK.M.; Peng, F.Z.; Li, Y.; Baoming, G. Quasi-Z-Source Inverter-Based Photovoltaic Generation System With Maximum Power Tracking Control Using ANFIS. IEEE Trans. Sustain. Energy2013, 4, 11-20.

[15] Mohamed, A.A.S.; Berzoy, A.; Mohammed, O. Design and Hardware Implementation of FL-MPPT Control of PV Systems Based on GA and Small-Signal Analysis. IEEE Trans. Sustain. Energy2017, 8, 279-290.

[16] Wang, L.; Singh,C. Population-Based Intelligent Search in Reliability Evaluation of Generation Systems with Wind Power Penetration. IEEE Trans. on Power Systems.2008, 23, 1336-1345.

[17] Koad, R.B.A.; Zobaa, A.F.; El-Shahat, A. A Novel MPPT Algorithm Based on Particle Swarm Optimisation for Photovoltaic Systems. IEEE Trans. Sustain. Energy2017, 8, 468-476.

[18] Priyadarshi, N.; Sharma, A.K.; Azam, F. A Hybrid Firefly-Asymmetrical Fuzzy Logic Controller based MPPT for PV-Wind-Fuel Grid Integration. Int. J. Renew. Energy Res.2017, 7, 1546-1560.

[19] Sundareswaran, K.; Sankar, P.; Nayak, P.S.R.; Simon, S.P.; Palani, S. Enhanced Energy Output From a PV System Under Partial Shaded Conditions Through Artificial Bee Colony. IEEE Trans. Sustain. Energy 2015, 6, 198-209.

[20] Kalaam, R.N.; Muyeen, S.M.; Al-Durra, A.; Hasanien, H.N.; Al-Wahedi, K. Optimisation of controller parameters for grid tied photovoltaic system at faulty network using artificial neural network-based cuckoo search algorithm. IET Renew. Power Gen. 2017, 11, 1517-1526.

[21] Priyadarshi, N., Padmanaban S., Mihet-Popa L., Blaabjerg, F., Azam F.: 'Maximum Power Point Tracking for Brushless DC Motor-Driven Photovoltaic Pumping Systems Using a Hybrid ANFISFLOWER Pollination Optimization Algorithm', MDPI Energies, 2018, 11(1), pp. 1-16.

[22] Priyadarshi, N., Padmanaban, S., Maroti,P.K., Sharma. A.: 'An Extensive Practical Investigation of FPSO-Based MPPT for Grid Integrated PV System Under Variable Operating Conditions With AntiIslanding Protection', IEEE System Journal, 2018, pp. 1-11.

[23] Priyadarshi, N., Padmanaban, S., Bhaskar, M.S., Blaabjerg, F., Sharma, A.: ‘A Fuzzy SVPWM Based Inverter Control Realization of Grid Integrated PV-Wind System with FPSO MPPT Algorithm for a Grid-Connected PV/Wind Power Generation System: Hardware Implementation', IET Electric Power Applications, 2018, pp. 1-12 
[24] Alanisamy, R.; Mutawakkil, A.U.; Selvakumar, K.; Karthikeyan, D. Modelling and simulation of z source inverter based grid connected PV system. In Proceedings of 2014 IEEE International Conference on Computational Intelligence and Computing Research. 2014, pp. 1-4.

[25] Kumaran B.A.; Sekhar, C.S.A.; Bala, V. PV Powered Quasi Z-Source Inverter For Agricultural Water Pumping System. In Proceedings of Third International Conference on Science Technology Engineering \& Management (ICONSTEM). 2017, pp. 544-549.

[26] Haji-Esmaeili, M.M.; Babaei, E.; Sabahi, M. High Step-Up Quasi-Z Source DC-DC Converter. IEEE Trans. Power Electron. 2018, pp. 1-1,doi: 10.1109/TPEL.2018.2810884.

[27] Tey, K.S.; Mekhilef, S.; Seyedmahmoudian, M.; Horan, B.; Oo, A.T.; Stojcevski, A. Improved Differential Evolution-based MPPT Algorithm using SEPIC for PV Systems under Partial Shading Conditions and Load Variation. IEEE Trans. on Ind. Info. 2018, 1-1, doi: 10.1109/TII.2018.2793210. 